\title{
Two new species of Idris Foerster (Hymenoptera: Platygastridae) from Southeastern Brazil, parasitoids of Argyrodes elevatus Walckenaer (Araneae: Theridiidae) and Scytodes sp. (Araneae: Scytodidae)
}

\author{
Cecilia MARGARÍA ${ }^{1,2}$, Marta LOIÁCONO ${ }^{1}$, Marcelo O. GONZAGA ${ }^{3}$ \& Daniel AQUINO \\ ${ }^{1}$ Museo de La Plata, Paseo del Bosque s/n (1900) La Plata, Buenos Aires, Argentina. cmargaria@fcnym.unlp. \\ edu.ar. 'Zoología Agrícola, Facultad de Ciencias Agrarias y Forestales, 60 y 118 (1900) La Plata, Buenos Aires, \\ Argentina. ${ }^{3}$ Universidade Federal de Uberlândia, Instituto de Biologia, Campus Umuarama, Bloco 2D, 38400- \\ 902 - Uberlândia, Minas Gerais, Brazil.
}

\begin{abstract}
In this study two new species of Idris Foerster (Platygastridae) are described and illustrated: I. argyrodes sp. nov. and I. scytodes sp. nov., from specimens reared from eggs of the spider species Argyrodes elevatus Walckenaer (Theridiidae) and Scytodes sp. (Scytodidae) collected in Minas Gerais State, Brazil. Scytodidae is a new host family for Idris.
\end{abstract}

Key words: Idris, endoparasitoids, spiders, eggsacs, Scytodes, Argyrodes

Resumen: Se describen e ilustran dos nuevas species de Idris Foerster (Platygastridae): I. argyrodes sp. nov. e I. scytodes sp. nov., emergidas de sacos de huevos de arañas de las species Argyrodes elevatus Walckenaer (Theridiidae) y Scytodes sp. (Scytodidae) recolectadas en el estado de Minas Gerais, Brasil. Scytodidae es una nueva familia hospedadora para Idris.

Palabras clave: Idris, endoparasitoides, arañas, sacos de huevos, Scytodes, Argyrodes

\section{INTRODUCTION}

Insects associated with spider eggsacs have been subject of great interest. Most species behave as predators -Ichneumonidae and most of Chalcidoidea (Hymenoptera), Diptera, and Mantispidae (Neuroptera) - and only a few act as endoparasitoids, completing their development at the expense of a unique spider egg. These true parasitoids are known in two families of hymenopterans: Platygastridae (ex Scelionidae) and Encyrtidae. Their larvae develop inside the egg, and after consuming it, pupate and adults emerge at the same time of spiders (Howard, 1892; Auten, 1925; De Santis, 1964; Eason et al., 1967; Evans, 1969; Askew, 1971; Valerio, 1971; Austin, 1984, 1985; Fitton et al., 1987; La Salle, 1990; Loiácono \& Margaría, 2004; Margaría et al., $2006 \mathrm{a}, \mathrm{b})$.

The tribe Baeini is unique among Platygastridae as endoparasitoids of the spider eggs whereas all other platygastrids parasitize insect eggs (Carey et al., 2006). They are ubiq- uitous in most habitats and are postulated to be important regulating agents of spider populations (Iqbal \& Austin, 2000). Host spiders are restricted to three main environments: soil and leaf litter, under the bark of trees, and foliage of shrubs and bushes (Stevens \& Austin, 2007).

Members of the tribe Baeini can be recognized by the combination of three synapomorphies-plus-biological characteristics: female antenna with four fused, usually compact clavomeres; antennal scape not reaching the level of the anterior ocellus, the convex outer surface of the tridentate mandibles, and their behavior of attacking eggsacs of spiders (Austin \& Field, 1997). Molecular studies have shown that most Baeini (Idris Foerster, Ceratobaeus Ashmead, Baeus Haliday and Odontacolus Priesner) form a monophyletic group, but that the australasian genera Mirobaeoides Dodd and Neobaeus Austin are more closely related to other genera of platygastrids associated with non-spiders hosts (Carey et al., 2006; Murphy et al., 2007; Stevens $\&$ Austin, 2007). Among Baeini there are still 
many undescribed species (Steven \& Austin, 2007). Mapping of wing-reduction states that occur in the Baeini revealed multiple wing-reduction events, possibly associated with adaptations for searching host egg masses in cryptobiotic habitats, and/or penetrating the silk eggsacs of spiders (Carey et al., 2006).

The genus Idris is cosmopolitan and contains 164 species associated with 11 families of spiders, among which are cited Dictynidae, Salticidae, Senoculidae and Theridiidae. Five species occur and are exclusively known from the Neotropical region: Idris aureus Girault from Peru, I. cubensis (Gahan) from Cuba, and I. fascipennis (Ashmead), I. ochraceus (Ashmead) and I. subfuscus (Ashmead) from the Antilles (Johnson, 2004, 2015). Only the biology of I. ovivorus is known, which develops as endoparasitoid of eggsacs of Ctenus sp. (Ctenidae); I. cubensis has been associated to an unidentified spider eggsac (Loiácono \& Margaría, 2013).

The aim of this contribution is the study of endoparasitoids of the genus Idris reared from spider eggsacs from Minas Gerais state, Brazil.

\section{MATERIAL AND METHODS}

Eggsacs of Scytodes sp. (Scytodidae) and Argyrodes elevatus Walckeaner (Theridiidae) were collected in an urban park (Parque do Sabiá - 18 ${ }^{\circ} 54^{\prime} 43^{\prime \prime} \mathrm{S}, 48^{\circ} 14^{\prime} 06^{\prime \prime} \mathrm{W}$ ) located in the eastern sector of the municipality of Uberlândia, State of Minas Gerais, Brazil. The park comprises an area of $1.85 \mathrm{Km}^{2}$ with 35 ha covered by woody savannas (Cerradão) and semideciduous forest. All the eggsacs collected were immediately placed in containers covered with a fine-mesh cloth and kept in the laboratory until the emergence of microhymenopterans or spiders. The emerged specimens were fixed in $70 \%$ alcohol.

Morphological terms follow Masner (1980), and Masner \& Denis (1996). Measurements are given in micrometers $(\mu \mathrm{m})$ as length or length:width. Abbreviations used are: $\mathrm{A}=$ antennal segments $\left(\mathrm{A}_{1}-\mathrm{A}_{6}\right), \mathrm{T}=$ metasomal terga $\left(\mathrm{T}_{1}-\mathrm{T}_{\mathrm{n}}\right)$. Samples examined herein were compared with photos of the holotype female of Idris ochraceus (Ashmead, 1894) deposited at British Museum of Natural History from Saint Vincent, West Indians [BMNH(E)\#969515].

Type material of the new species are deposited in the collections of Universidade Federal de São Carlos (DCBU, Curator Angélica M PenteadoDias), in Brazil, and Museo de La Plata (MLP) in Argentina. Voucher specimens of Scytodes sp. were deposited in the arachnological collection of Instituto Butantan, São Paulo, Brazil (IBSP) and voucher specimens of Argyrodes elevatus were deposited in the collection of Universidade Federal de Minas Gerais (UFMG), Minas Gerais, Brazil.

Idris scytodes Margaría, Loiácono et Aquino sp. nov.

(Fig. 1A, B)

Description: Female: Body length $1100 \mu \mathrm{m}$ (Fig. 1A). Body color light brown, legs including coxae, mandibles, labrum, antennae, T1 yellowish; wings slightly infuscate.

Head in dorsal view transverse, (387-416:337362) wider than mesosoma, vertex with granular sculpture. Head in lateral view (501-562:228255) higher than long; (228-255:312-350) lower than mesosoma. Head in frontal view (Fig. 1B) slightly higher than wide (384:320), with granular sculpture, except frons smooth and shiny with semidecumbent hairs, cheeks near mandibular base with longitudinal striae; occiput perpendicular, forming with the vertex a sharp angle which is margined by a delicate carina; eyes oval and with short hairs; eye height:interorbital space (187:118); lateral ocelli very near the eye margin and also close to occiput margin; vertex, face, and cheeks smooth; the frons immediately above antennae not shiny (opaque) and without median carina; eye height:malar space (187:118). Head in posterior view with occciput below hyperoccipital carina with microgranular sculpture. Antennal segments in the following relative proportions: $A_{1}$ (125:35), $A_{2}$ (52:33), $A_{3}$ (23:21), $A_{4}$ (10:23), $A_{5}(11.6: 23), A_{6}(10: 29)$, club (127.7:46) abruptly differentiated from funicle, antennal club segmentation straight and very poorly differentiated.

Mesosoma in dorsal view longer than wide (375-400:337-362), mesoscutum transverse (337362:212-225) with semidecumbent hairs, and granular sculptured; scutellum subtriangular longer than wide (225-250:150) with same pilosity and sculpture as mesoscutum; propodeum evenly canaliculated, posterolateral corner only slightly projecting, median keels slightly projecting; mesosoma in lateral view longer than high (375-400:312-350); scutellar ring projecting moderately over dorsellum; lateral side of pronotum predominantly granular, without distinct crenulae in lower third, epomium sharp; posterolateral corners of propodeum projecting slightly. Wings fully developed, extending a little beyond apex of metasoma; submarginal vein with row of 


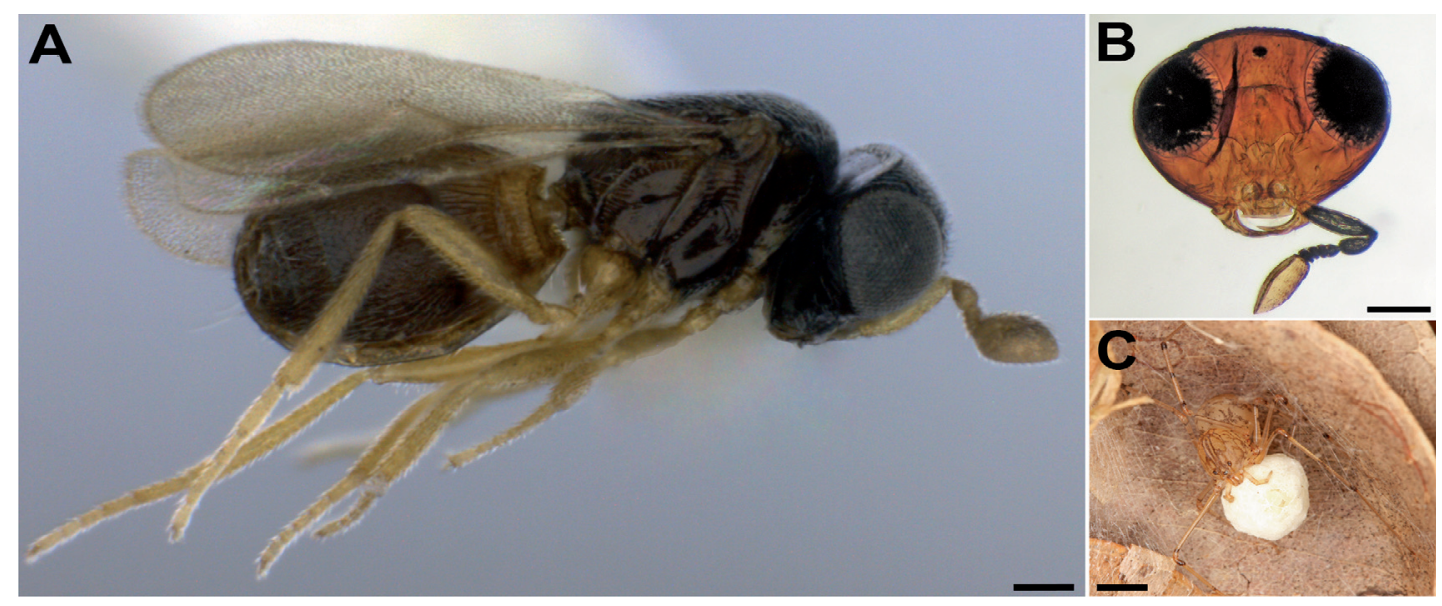

Fig. 1. Idris scytodes sp. nov. Female. A. habitus, B. head in frontal view, C. host species of Idris scytodes: Scytodes sp. carrying its eggsac within a shelter made of dry curled leaves contructed by Tidarren haemorrhoidale (Bertkau) (Theridiidae). Scales: A, B: $0.1 \mathrm{~mm}$. c: $5 \mathrm{~mm}$.

long semierect bristles, distinctly surpassing fore margin of wing.

Metasoma as long as head plus mesosoma, ovate, narrowed basally; T1 longitudinally striated, about twice as broad as long; T2 smooth, its basal one third with rather dense short narrow longitudinal striae; T3 and following tergites finely sculptured. Metasomal terga in the following relative proportions $\mathrm{T}_{1}(50: 200), \mathrm{T}_{2}(137: 225)$, $\mathrm{T}_{3}$ (150:350), $\mathrm{T}_{4}$ (87:262). Metasoma in lateral view slightly convex, sternites finely sculptured as tergites.

Male: unknown

Distribution: Brazil, Minas Gerais State,

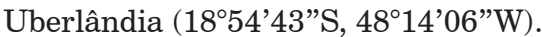

Parasitoid biology: Reared from an eggsac of Scytodes sp. (Scytodidae) (new family host record).

Host biology (Fig. 1C): Individuals of Scytodes sp. were collected invading webs of the theridiid spiders Latrodectus geometricus Koch, in an urban park in Uberlândia (Parque do Sabiá - 18 $\left.54^{\prime} 43^{\prime \prime} \mathrm{S}, 48^{\circ} 14^{\prime} 06^{\prime \prime} \mathrm{W}\right)$, and Tidarren haemorrhoidale (Bertkau) in an Eucaliptus plantation in Estrela do Sul (Fazenda Nova Monte Carmelo

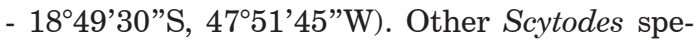
cies were previously reported preying on spiders (Nentwig 1985; Jackson et al. 1998; Li et al., 1999; Ades \& Ramires, 2002). Araneophagy in Scytodes is favoured by its capacity to spit a gummy secretion over their prey and is possibly widespread within the genus. Scytodes sp. eggsacs are composed of a layer of loose silk threads and are continuously transported and protected by the mothers (Fig. 1C). Eggs, however, are probably easily accessed by parasitoids. Idris scytodes $\mathrm{sp}$. nov. was found in an eggsac of a female occupying a web of $L$. geometricus under a park bench in Parque do Sabiá, close to the forested area.

Material examined: Holotype female: Brazil, Minas Gerais State, Uberlândia (18 $54^{\prime} 43^{\prime \prime}$, 48 14'06”'W), 2-IV-2010, Tozzo-Neto coll. (DCBU). Paratypes, 3 females, same data as holotype (MLP).

Etymology: the specific name was taken from the host genus Scytodes Blackwall (Scytodidae).

Remarks: Idris scytodes sp. nov. agrees with $I$. ochraceus (Ashmead) in the following features: body color light brown, antennal club segmentation straight and very poorly differentiated, transparent wings, and T1 longitudinally striate. Idris scytodes differs from I. ochraceus principally by the size of A3 and the sculpture of T2; I. scytodes is also related to I. argyrodes, as discussed below, but differs principally by size of A3 and the sculpture of T2. The type of $I$. ochraceus (Fig. 2A-D) is in the British Museum, and we have verified the characters of the original description with photos taken by David Notton, Senior Curator, Hymenoptera Natural History Museum, United Kingdom. Ashmead (1894) described "bare eyes" but we observed very fine and short hairs. Idris argyrodes and I. scytodes are easily separated from I. aureus and $I$. fascipennis principally by the different body color. The sculpture of the first abdominal segments allows to differenciate Idris scytodes from I. argyrodes, I. ochraceus and I. cubensis. Idris argyrodes differs from I. ochraceus by the presence of eye pilosity and the shape of T2, and differs from I. cubensis by the shape of A3. 


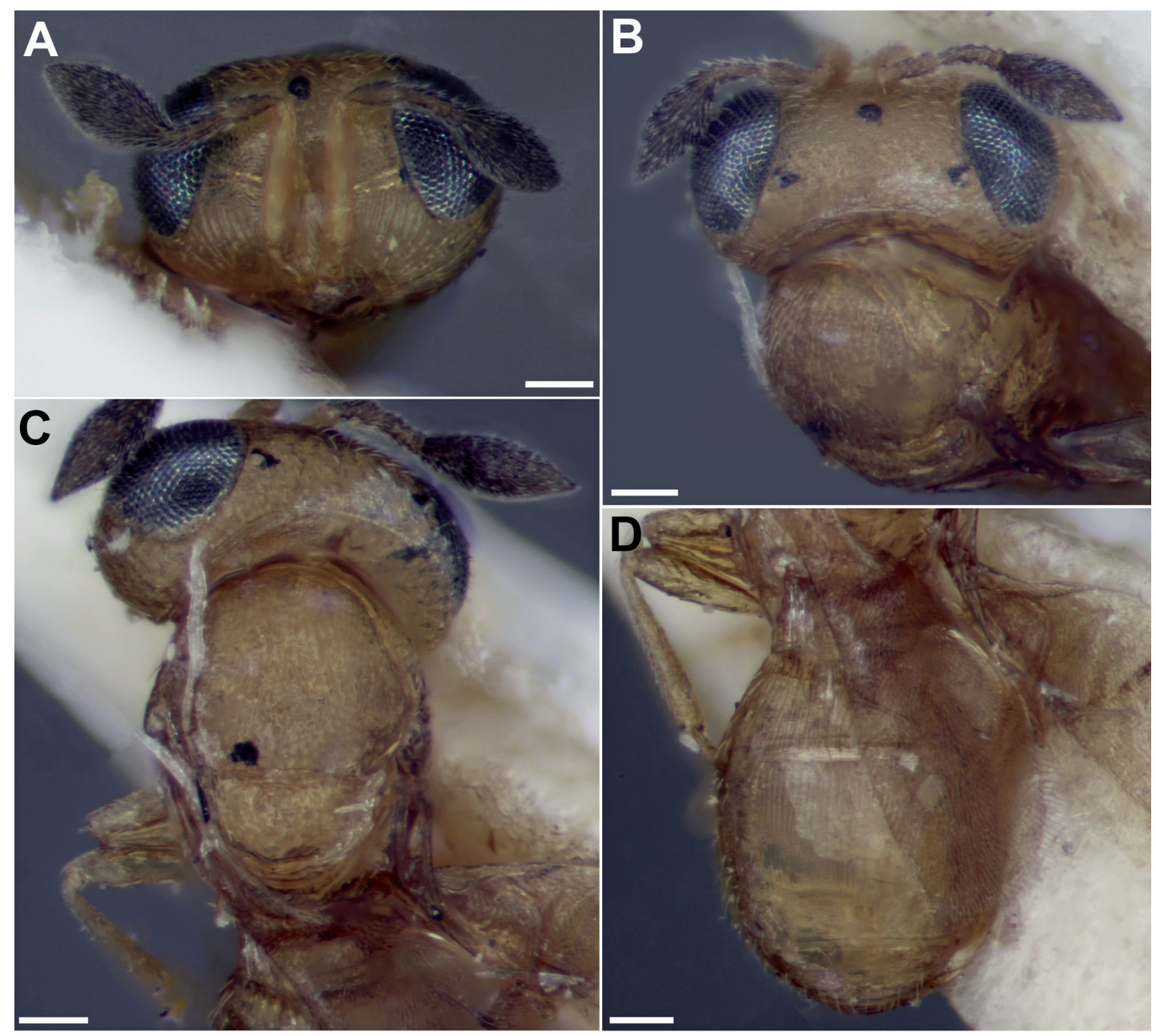

Fig. 2. Idris ochraceus (Ashmead). Female. A. head in frontal view, B. head and pronotum in dorsal view, C. mesosoma in dorsal view, D. metasoma in dorsal view. Scales: $0.1 \mathrm{~mm}$

$$
\begin{gathered}
\text { Idris argyrodes Margaría, Loiácono et Aquino } \\
\text { sp. nov. }
\end{gathered}
$$$$
\text { (Fig. 3a, B, C) }
$$

Description: Female: Body length $1900 \mu \mathrm{m}$.

Body color light brown, antennae, legs including coxae and T1 yellowish; wings slightly infuscate. Head in dorsal view transverse, slightly wider than mesosoma (400:256), vertex with granular sculpture. Head in lateral view higher than long (287:175), slightly lower than mesosoma (287:300). Head in frontal view (Fig. 3A) slightly wider than high (12:9), with slightly reticulate sculpture and semidecumbent hairs, cheeks near mandibular base with short striae; occiput perpendicular, forming with the vertex a sharp angle which is margined by a delicate carina; eyes rounded and with short hairs; eye height:interorbital space (149:176); lateral ocelli very near the eye margin and also close to occiput margin; the frons immediately above antennae not shinny (mate) and without median carina; eye heigh:malar space (149:93). Antennal segments in the following relative proportions: $A_{1}(118: 29), A_{2}(54: 27), A_{3}(25: 17), A_{4}(15: 17), A_{5}$ (13:19), $A_{6}(13: 23)$, club (122:66) abruptly differentiated from funicle (Fig. 3B), antennal club segmentation rounded and poorly differentiated. Mesosoma in dorsal view (Fig. 3C) longer than wide (344:256) (350-375:312-337), mesoscutum transverse(144:208) (212:337) with semidecumbent hairs, and granular sculpturing; scutellum rounded wider than long (112-125:162) with same pilosity and sculpturing as mesoscutum; propodeum evenly canaliculated, posterolateral corner only slightly projecting, median keels slightly 


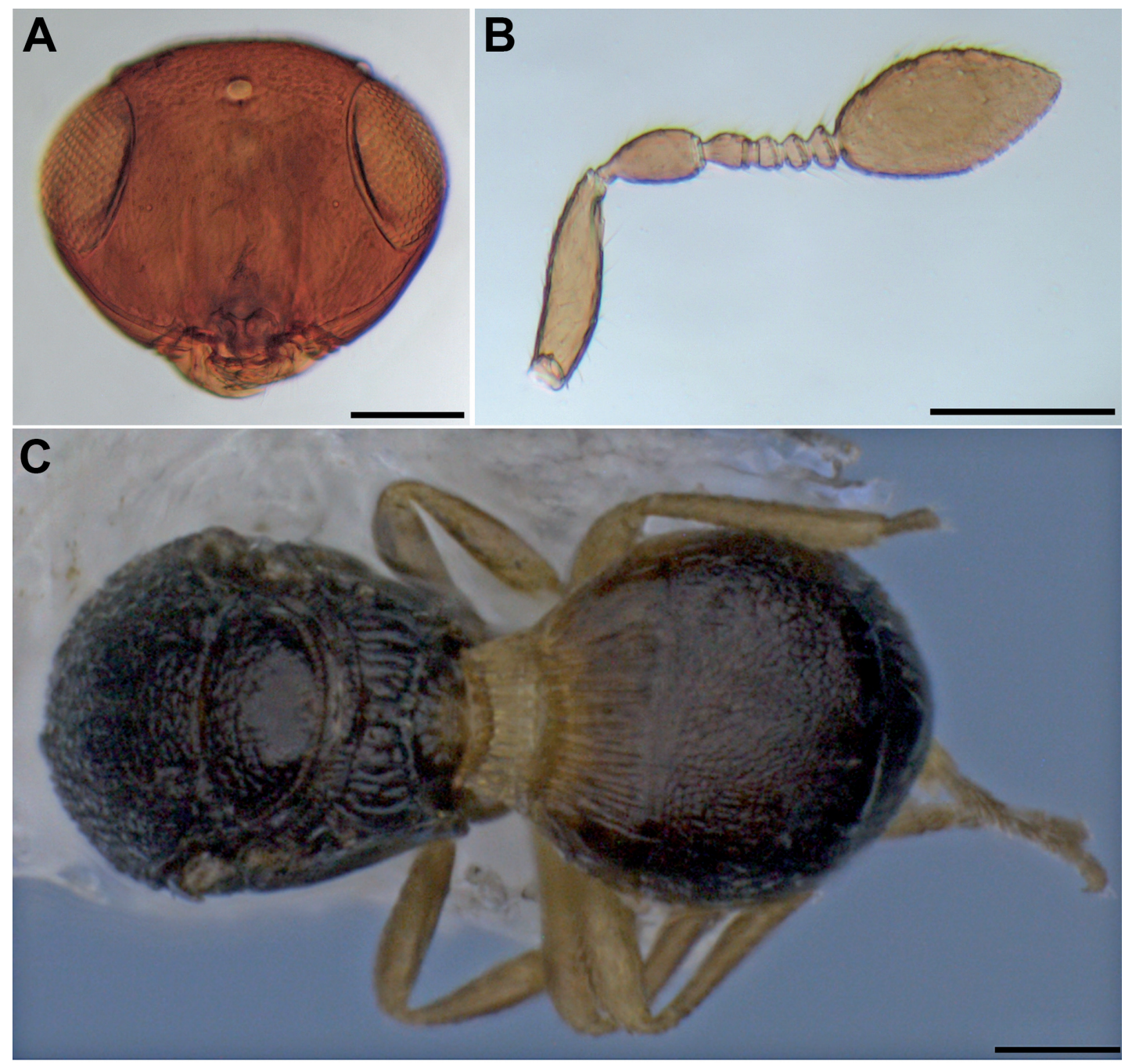

Fig. 3. Idris argyrodes sp. nov. Female. A. head in frontal view, B. antenna, C. meso and metasoma in dorsal view. Scales: $0.1 \mathrm{~mm}$.

projecting; mesosoma in lateral view longer than high (350-375:287-300); scutellar ring projecting moderately over dorsellum; lateral side of pronotum predominantly granular, without distinct crenulae in lower third, epomium sharp; posterolateral corners of propodeum projecting slightly. Wings fully developed, extending a little beyond apex of metasoma; submarginal vein with row of long semierect bristles, distinctly surpassing fore margin of wing.

Metasoma (Fig. 3C) as long as the head plus mesosoma, ovate, narrowed basally; T1 and T2 longitudinally striated, T1 about twice as broad as long; T3 and following tergites finely sculptured. Metasomal terga in the following relative proportions $\mathrm{T}_{1}(104: 46), \mathrm{T}_{2}(182: 77), \mathrm{T}_{3}(39), \mathrm{T}_{4}$
(31:10). Metasoma in lateral view slightly convex, sternites finely sculptured as tergites.

Male: unknown

Distribution: Brazil, Minas Gerais state, Uberlândia, Uberlândia locality $\left(18^{\circ} 54^{\prime} 37^{\prime} \mathrm{S}\right.$, $48^{\circ} 13^{\prime} 45^{\prime \prime} \mathrm{W}$ ).

Parasitoid biology: Reared from eggsacs of Argyrodes elevatus Walckenaer (Theridiidae).

Host biology: Argyrodes elevatus (Fig. 4A) is a kleptoparasitic spider often found in webs of larger spiders of the families Araneidae, Nephilidae and Theridiidae (Vollrath, 1979; Cobbold \& Su, 2010; Silveira \& Japyassú, 2012). Individuals of this species usually feed with the hosts to obtain food, exploiting host's efforts involved in capturing and subduing processes, and having access to 


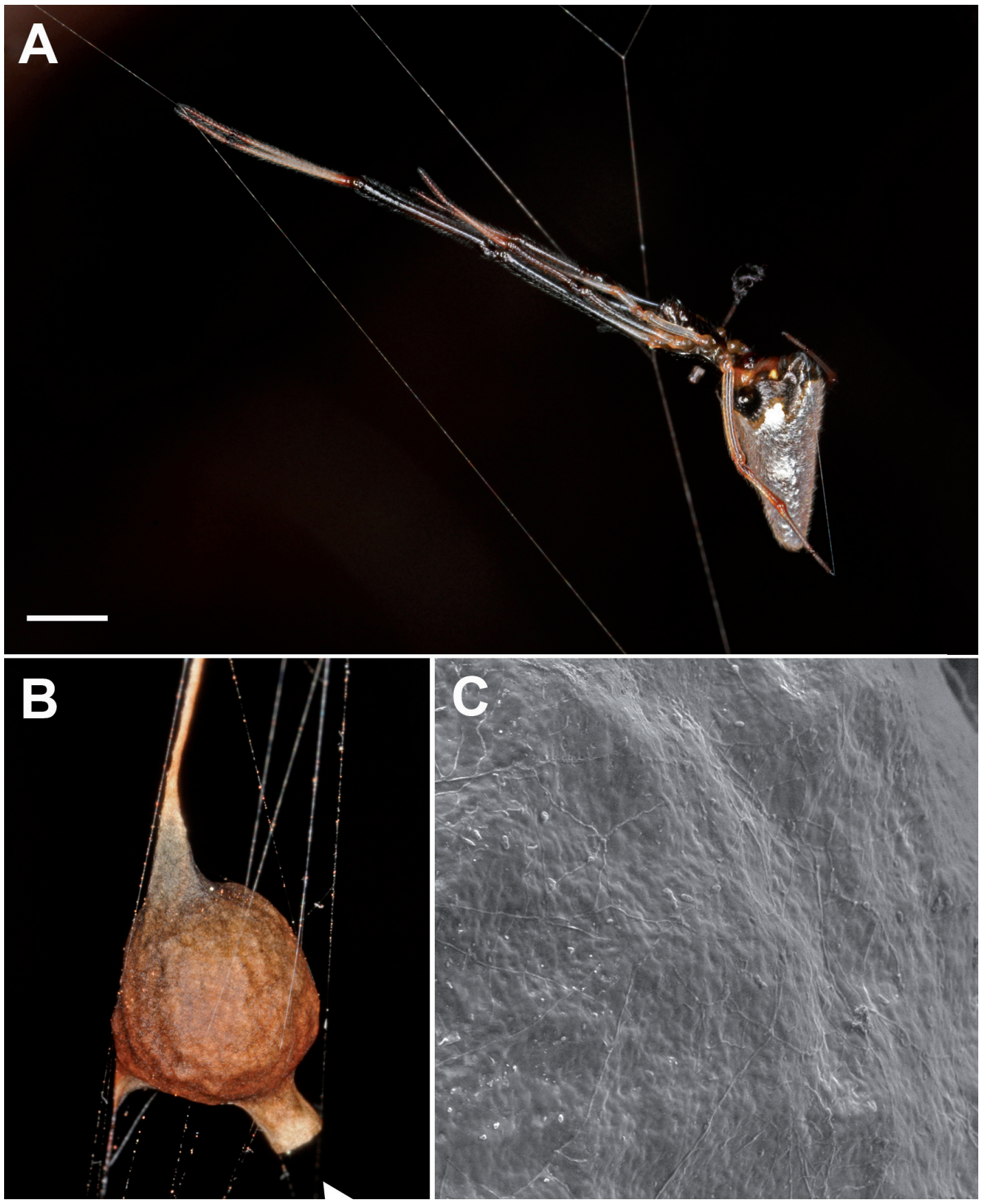

Fig. 4. Host species of Idris argyrodes sp. nov. A. Argyrodes elevatus in resting position, holding web threads connected to the web of its host, Nephila clavipes (Linnaeus) (Nephilidae); B. eggsac of A. elevatus. The arrow indicates the openning used by spiderlings to get out; C. Detail of the wall of the eggsac of $A$. elevatus, showing its compact and resistent structure. Scales: A and B. $1 \mathrm{~mm}$, C. $300 \mu \mathrm{m}$.

predigested items (Vollrath, 1979). In addition, A. elevatus is able to prey on their hosts (Cobbold \& Su, 2010; Silveira \& Japyassú, 2012) and on host's eggsacs, to capture small prey items entangled by the web and ignored by their hosts and to steal wrapped preys stored by their hosts 
(Silveira \& Japyassú, 2012). Interestingly, there are a few cases of observations of males offering stolen prey items to females as nuptial gifts (Cobbold \& Su, 2010; Uetz et al., 2010). Unlike other Argyrodines, such as Faiditus ululans (O. Pickard-Cambridge) (Cangialosi, 1990), females of A. elevatus leave their eggsacs unattended, attached to threads of the host's web (Marcelo O. Gonzaga pers. obs., Vollrath, 1987). This behavior may facilitate the attack by parasitoid species and/or egg predators. The eggsacs of $A$. elevatus, however, are composed of a very resistant and dense silk layer (Fig. 4B, C), which possibly include substances other than those usually present in silk threads, to confer the tough structure involved in egg protection. Spiderlings left the eggsac through a hole situated at the bottom position (indicated by an arrow in Fig. 4B). The same opening is probably used by the parasitoid to have access to the eggs. Idris argyrodes sp. nov. was found in an eggsac attached to the web of Nephila clavipes (Linnaeus) in the forested area of Parque do Sabiá, in Uberlândia.

Material examined: Holotype female: Brazil, Minas Gerais State, Uberlândia, Uberlândia

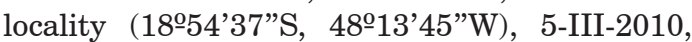
Gonzaga coll. (DCBU). Paratypes, 2 females, same data as holotype (MLP).

Etymology: the specific name was taken from the host genus Argyrodes Simon (Theridiidae).

Remarks: Considering the Neotropical species, Idris argyrodes sp. nov. is also related to I. ochraceus (Ashmead) (Fig. 2-D) but differs by the size of T2. Idris argyrodes sp. nov. differs from I. scytodes sp. nov. by the narrower interorbital space, rounded internal border of eyes, antennal club longer than wide, and cheeks with longer striae.

\section{ACKNOWLEDGEMENTS}

Our thanks to Dr. David Notton, Senior Curator, Hymenoptera Natural History Museum, United Kingdom. We also thank Duratex S.A. for providing logistical support and for allowing the study in Fazenda Nova Monte Carmelo. This Project was supported by Secretaría de Ciencia y Técnica de la Universidad Nacional de La Plata (UNLP), Fundação de Amparo à Pesquisa do Estado de Minas Gerais (Proc. APQ-02104-14, CRA-30058/12), Instituto Nacional de Ciência e Tecnologia dos Hymenoptera Parasitoides da Região Sudeste (HYMPAR/Sudeste - CNPq/ CAPES/Fapesp) and Conselho Nacional de Desenvolvimento Científico e Tecnológico (Proc. 306157/2014-4; 403733/2012-0, 445832/2014-2).

\section{BIBLIOGRAPHY}

Ades, C. \& E.N. Ramires. 2002. Asymmetry of leg use during prey handling in the spider Scytodes globula (Scytodidae). Journal of Insect Behavior 15: 563-570.

Ashmead, W.H. 1894. Report on the parasitic Cynipidae, part of the Braconidae, the Ichneumonidae, the Proctotrypidae, and part of the Chalcidinae. Part III. Zoological Journal of the Linnean Society of London25: 215- 216.

Askew, R.R. 1971. Parasitic Insects. Heinemann Educational (ed.), London, $316 \mathrm{pp}$.

Austin, A.D. 1984. The fecundity, development and host relationships of Ceratobaeus spp. (Hymenoptera: Scelionidae) parasites of spiders eggs. Ecological Entomology 9: 125-138.

Austin, A.D. 1985. The function of spider egg sacs in relation to parasitoids and predators, with special reference to the Australian fauna. Journal of Natural History 19: 359- 376.

Austin, A.D. \& A.D. Field. 1997. The ovipositor system of scelionid and platygastrid wasps (Hymenoptera: Platygastroidea): comparative morphology and phylogenetic implications. Invertebrate Taxonomy 11: 1-87.

Auten, M. 1925. Insects associated with spider nests. Annuals of the Entomological Society of America 18: $240-250$.

Cangialosi, K. 1990. Life cycle and behavior of the kleptoparasitic spider, Argyrodes ululans (Araneae, Theridiidae). Journal of Arachnology 18: 347-358.

Carey, D.; Murphy, N.P. \& A.D. Austin. 2006. Molecular phylogenetics and the evolution of wing reduction in a tribe of parasitoid wasps (Hymenoptera: Scelionidae: Baeini). Invertebrate Systematic 20: 489-501.

Cobbold, S.M. \& Y.C. Su. 2010. The host becomes dinner: possible use of Cyclosa as a nuptial gift by Argyrodes in a colonial web. Journal of Arachnology 38:132-134.

De Santis, L. 1964. Himenópteros Argentinos parásitos de ootecas de arañas. Notas de la Comisión de Investigaciones Científicas de la Provincia de Buenos Aires 2: 1-13.

Eason, R.R., W.B. Peck \& W.H. Whitcomb. 1967. Notes on spider parasites, including a reference list. Journal of Kansas Entomology Soc. 40: 422- 434.

Evans, R.E. 1969. Parasites of spiders and their eggs. Proceeding of the Birmingham Natural History Society 21: 156-168.

Fitton, M.G., M.R. Shaw \& A.D. Austin. 1987. The Hymenoptera associated with spiders in Europe. Zoological Journal of the Linnean Society 90: 6593.

Howard, L.O. 1892. The hymenopterous parasites of spiders. Proceeding of the Entomological Society of Washington 2: 290-303.

Iqbal, M. \& A.D. Austin. 2000. A preliminary phylogeny for the Baeini (Hymenoptera: Scelionidae) endoparasitoids of spider eggs. In: The Hymenoptera: evolution, biodiversity and biological control. Austin y 
Dowton (eds.), CSIRO, Melbourne, 468 pp.

Jackson, R.R., Li, D., Fijn, N. \& A. Barrion. 1998. Predator-prey interactions between aggressivemimic jumping spiders (Salticidae) and araneophagic spitting spiders (Scytodidae) from Philippines. Journal of Insect Behavior 11: 319-342.

Johnson, N.F. 2004. Platygastroidea. http://atbi.biosci. ohio-state.edu:210/ hymenoptera/eol_scelionidae. home (access april 2015).

Johnson, N.F. 2015. Hymenoptera Online (HOL). Available from http://hol.osu.edu/index. html?id=195000. [accessed 27 November 2015].

LaSalle, J. 1990. Tetrastichinae (Hymenoptera: Eulophidae) associated with spider egg sacs. Journal of Natural History 24: 1377-1389.

Li, D., Jackson R.R. \& A. Barrion. 1999. Parental and predatory behavior of Scytodes sp., an araneophagic spitting spider (Araneae: Scytodidae) from the Philippines. Journal of Zoology 247: 293-310.

Loiácono, M.S. \& C.B. Margaría. 2004. Las especies del género Baeus (Hymenoptera: Scelionidae) endoparasitoides de ootecas de arañas en la región neotropical. Acta Zoologica Mexicana 20: 83- 90.

Loiácono, M.S. \& C.B. Margaría. 2013. Avispitas que atacan arañas. Boletín de la Sociedad Entomológica Argentina. $\mathrm{N}^{\circ} 24$ (1-2): 2-4 2013

Margaría, C.B., M.S. Loiácono \& M.O. Gonzaga. 2006a. Two new species of Baeus (Hymenoptera: Scelionidae) from South-eastern Brazil parasitoids of Anelosimus (Araneae: Theridiidae). Zootaxa 1162: 45- 52.

Margaría, C.B., M.S. Loiácono \& M.O. Gonzaga. 2006b. A new species of Baeus (Hymenoptera: Scelionidae) from Brazil, parasitoid of Cyclosa morretes (Araneae: Araneidae). Entomological News 117: 181- 187.

Masner, L. 1980. Key to genera of Scelionidae of the Holarctic region, with descriptions of new gen- era and species (Hymenoptera: Proctotrupoidea). Memoirs of the Entomological Society of Canada 113: 1-54.

Masner, L. \& J. Denis. 1996. The nearctic species of Idris Foerster. Part I: The melleus-group (Hymenoptera: Scelionidae). Canadian Entomology 128: 85-114.

Murphy, N.P., D. Carey, L.R. Castro, M. Dowton \& A.D. Austin. 2007. Phylogeny of the platygastroid wasps (Hymenoptera) based on sequences from 18S rRNA, 28S rRNA and cytochrome oxydase I genes: implications for the evolution of the ovipositor system and hosts relationships. Biological Journal of the Linnean Society 91: 653-669.

Nentwig W. 1985. Feeding ecology of the tropical spitting spider Scytodes longipes (Araneae, Scytodidae). Oecologia 65:284-288.

Silveira, M.C. \& H.F. Japyassú. 2012. Notes on the behaviour of the kleptoparasitic spider Argyrodes elevatus (Theridiidae, Araneae). Rev. Etol. 11:56-67.

Stevens, N.B. \& A.D. Austin. 2007. Systematics, distribution and biology of the Australian 'micro-flea' wasps, Baeus spp. (Hymenoptera: Scelionidae): parasitoids of spider eggs. Zootaxa 1499: 1-45.

Uetz, G.W., McCrate, A. \& Hieber, C.S. 2010. Stealing for love? Apparent nuptial gift behavior in a kleptoparasitic spider. Journal of Arachnology 38:128131.

Valerio, C.E. 1971. Parasitismo en huevos de araña Achaearanea tepidariorum (Koch) (Araneae: Theridiidae) en Costa Rica. Revista de Biología Tropical 18: 99-106.

Vollrath, F. 1979. Behaviour of the kleptoparasitic spider Argyrodes elevatus (Araneae, Theridiidae). Animal Behavior 27: 515-521.

Vollrath, F. 1987. Kleptobiosis in spiders. Pp 274-286, in Ecophysiology of Spiders. (W. Nentwig, ed.). Springer-Verlag, Berlin, Heidelberg, New York, Tokyo 